\title{
On the Permissibility of Free-Riding on the Global Lingua Franca
}

\author{
Siba Harb ${ }^{1,2}$ \\ Published online: 9 July 2020 \\ (c) The Author(s) 2020
}

\begin{abstract}
English today seems to be emerging as a global lingua franca. And a global lingua franca would be a global public good. Characteristically, being non-excludable, public goods are susceptible to free-riding: absent targeted distributive policies, some individuals can accrue a good's benefits without having contributed to the costs of its production. In this paper, I make two arguments. First, I argue, against Philippe Van Parijs, that Anglophones are not unfairly free-riding on the efforts of non-Anglophones of producing English as a global lingua franca. I defend the view that instances of what counts as unfair free-riding should be limited to free-riding on public goods that are co-operatively produced. Second, I suggest an alternative claim that is available for Van Parijs to make. Van Parijs believes a global lingua franca is required by global justice. This is a highly controversial claim. But if he is right, then Anglophones' free-riding on the global lingua franca while not an instance of unfair free-riding, may be objectionable nonetheless.
\end{abstract}

Keywords Linguistic justice $\cdot$ Free-riding $\cdot$ Lingua franca $\cdot$ Fairness principle $\cdot$ Global justice

English today is increasingly the language of communication between individuals with different mother tongues around the world. This suggests that English is emerging as a global lingua franca. A global lingua franca is a global public good. It is a good because of the expected communicative benefits of having a common language. It is a public good because it is both non-excludable and non-rival (Ostrom and Ostrom 2015, p. 7). Any speaker of the lingua franca can benefit from having a

Siba Harb

siba.harb@gmail.com

1 Institute of Philosophy, KU Leuven, Andreas Vesaliusstraat 2-Bus 3225, 3000 Leuven, Belgium

2 Department of Philosophy and Religious Studies, Utrecht University, Janskerkhof 13,

3512 BL Utrecht, The Netherlands 
common language that allows her to communicate beyond her linguistic community. And having additional individuals use the lingua franca does not diminish the good, quite the opposite. Finally, it is a global public good because its benefits can and often do extend beyond the borders of particular populations, particular countries, or even particular generations. English, to the extent that it is or will become a global lingua franca, would be a global public good. ${ }^{1}$

Characteristically, public goods are susceptible to free-riding. Given their nonexcludable nature, anyone can benefit from the goods. This allows, absent targeted distributive policies, for some individuals to free-ride: i.e. to accrue the good's benefits without having contributed to the costs attached to its production. This potential discrepancy between those who benefit and those who contribute raises at least two important concerns. Firstly, the absence or the limited contribution of some might render the provision of the good unsustainable. The availability of free-riding as an option may reduce the number of contributors, thereby standing in the way of reaching the critical number needed to produce and maintain the good. Secondly, even when there are no concerns of sustainability, there is the question of the fairness of benefitting from a public good without contributing duly to its provision.

In his thought-provoking work on the injustices that arise from the spread of English as a lingua franca, Philippe Van Parijs argues that the spread of English as a global lingua franca gives rise to the second type of concern about the fairness of benefitting from a public good (Van Parijs 2011, pp. 50-85). ${ }^{2}$ He points out that native speakers of English benefit from the global lingua franca without contributing to the cost of producing it; non-native speakers bear the cost. He concludes that native speakers of English unfairly free-ride on the global public good of the lingua franca and that for the spread of English to be just, native speakers ought to contribute their fair share to the production of the global lingua franca.

In this paper, I argue that native speakers of English (henceforth Anglophones) are not unfairly free-riding on the efforts of non-native speakers of English (henceforth non-Anglophones) to produce a global lingua franca (henceforth GLF). Van Parijs arrives at the wrong conclusion because he mistakenly assumes that long-term free-riding on important public goods is always unfair. I appeal to what I call the cooperative restriction view which states that instances of what counts as unfair freeriding should be limited to free-riding on public goods whose producers constrain themselves out of a sense of duty, under a system of public rules, in order to produce the good; co-operative schemes typically exemplify this. The co-operative restriction view suggests that it is not unfair to free-ride on public goods when the goods are the outcome of self-serving production efforts. I show that English as a GLF is an instance of self-serving production efforts; that is to say, it is not produced co-operatively in the relevant sense for concerns with the fairness of free-riding to arise. Next, I suggest an alternative claim that is available for Van Parijs to make.

\footnotetext{
1 That English is the emerging global lingua franca, and that it is a global public good are premises in this paper that I assume to be true. But see Lacey (2015), Ives (2009), Réaume (2015), and Romaine (2015) for skeptical arguments.

2 In earlier work, Van Parijs (2002) argues that any asymetric case of billingualism, where only one group learns the language of the other involves an injustice.
} 
Van Parijs believes a GLF is required by global justice. This is a highly controversial claim. But if he is right, then free-riding on the GLF while not an instance of unfair free-riding (in the sense that it does constitute unfair benefitting from the efforts of others), may nonetheless be impermissible. For while English as a GLF is not cooperatively produced, it is a separate question whether it ought to be co-operatively produced. I will argue that we have reasons to co-operatively produce goods whose production is required by justice. These reasons have to do with rejecting objectionable domination of producers over beneficiaries.

This paper is primarily a contribution to the nascent debate within linguistic justice about the injustices involved in the spread of English as a GLF. ${ }^{3}$ I should note that my argument, if successful, does not undermine Van Parijs's central conclusions about the injustices involved in the spread of a GLF. In Van Parijs's view, more troubling than the injustice of free-riding are the injustices of unequal opportunities and disparity of esteem that result from the spread of a GLF. ${ }^{4}$ It is nevertheless interesting to discuss the argument from free-riding as it is the argument that Van Parijs hoped would be the most ecumenical; unlike the arguments from equality of opportunity and equality of esteem, it is meant to be convincing to those many who reject the global egalitarian commitments underlying those two arguments (Van Parijs 2011, p. 51). Yet, as I shall argue, the argument from co-operation, if it is to succeed, must assume that a GLF is a requirement of global justice. But such an assumption is very controversial, largely narrowing the appeal of the argument. It also no longer allows Van Parijs to claim that non-Anglophones are owed compensation for the costs they have incurred.

A GLF is a public good the benefits of which are widened social, economic, and cultural opportunities (Van Parijs 2011, p. 15). One has access to these benefits if one is a speaker of the GLF. The costs of producing the GLF are the costs associated with the creation of additional speakers of English. According to Van Parijs, Anglophones free-ride on the GLF since they benefit from it but do not contribute to the cost of creating it (2011, pp. 50-53). By contrast, the non-Anglophones who

\footnotetext{
3 See De Schutter and Robichaud (2016), for a symposium on Van Parijsian Linguistic Justice. There, Robichaud (2015) argues that Anglophones are not unfairly free-riding because the production of English as a GLF is not a co-operative endeavor. Despite the apparent similarities between his conclusion and mine, there are significant differences in our approach and conclusions.

4 According to Van Parijs, the spread of English as a lingua franca can be thought to engender three forms of injustice. The first, what he terms co-operative injustice, is the subject of this paper. My choice to not present the argument in terms of co-operative justice is deliberate. The argument of this paper is that certain conditions ought to be met for the production of a public good to count as a co-operative endeavor, hence giving rise to concerns of fairness in co-operation. The second is inequality of opportunity: being native speakers of the lingua franca, Anglophones have better access to economic and communication opportunities (2011, pp. 87-113). The third is disparity of esteem: the spread of English as a lingua franca undermines equal respect and recognition of the collective identities of non-Anglophone language communities (pp. 117-130).
} 
learn English create benefits, contributing to the process of transforming English from a language spoken by some to a GLF. Non-Anglophones who learn English bear the entire cost of spreading the GLF, and the cost is not negligible. It comprises the financial and opportunity costs of mastering a language that is not one's native language (2011, p. 52).

It may seem surprising to claim that Anglophones do not contribute to the cost of creating the GLF; it is, after all, the Anglophones' language. It is important, however, to distinguish between two goods associated with English: the good of English qua GLF and the good of English qua particular language. Van Parijs's claim concerns the good of English qua GLF, i.e. the good of having English as a common, widespread language. He points out that English has emerged as a global lingua franca through morally neutral processes such as historical contingencies and micro-mechanisms regulating the learning and the speaking of a language. Against this background, each non-Anglophone who learns English constitutes an additional communication opportunity thereby expanding the circle of speakers and increasing the benefit for anyone speaking English (2011, pp. 9-19). Anglophones can avail themselves of the benefits provided by the competence in English of each additional speaker without having to take up any cost, for all that is required for them to benefit is competence in English which they have by virtue of being native speakers. ${ }^{5}$ To be sure, Anglophones have had to bear the cost of learning English. But that cost of learning one's native language is one that non-Anglophones have also had to bear. The cost in question here is the additional cost of learning a second language.

Van Parijs thinks it is unfair, hence, unjust that Anglophones free-ride. ${ }^{6}$ To see the unfairness, Van Parijs asks us to consider the following case (call it Dust) in which he shares a living space with his father-in-law for a few months:

... as soon as any amount of dust became visible, my father-in-law got [...] rid of it. As a result, all the cleaning was done before the level of dirtiness reached would have triggered my doing the cleaning myself [...]. No power relationship or altruism was involved [...]. Yet, the structure of the situation was such that I systematically benefited from my father-in-law's toil without contributing myself in any way to the public good he produced. Even on the generous assumption that neither I nor my offspring were responsible for any of the dust, this seemed unfair to me... (2011, p. 52)

Van Parijs sees an analogy between Dust and the case of the GLF. Finding the two cases analogous, and finding Dust to involve unfair free-riding, he concludes that the production of the GLF involves unfair free-riding. He further concludes that

\footnotetext{
5 Although, one could argue that Anglophones are incurring a cost for having English as a GLF, that of being doomed to being monolinguals thereby missing out on benefits associated with speaking more than one language. For an argument in this direction, see Swain (2014).

6 Van Parijs (2002, pp. 56-67) defends a principle of equal ratio of cost to benefit for the distribution of the benefits and costs over other solutions for fair co-operation such as a Gauthier solution (equal benefit sharing) or Church and King's (efficient cost sharing). For an article critiquing his choice of distributive principle, see Taylor (2014). Here, my target is not the distributive principle itself but the underlying assumption that there is a concern with fairness in the production of the GLF in the first place.
} 
the unfairness is an injustice that ought to be corrected: both the father-in-law and non-Anglophones ought to be compensated (2011, pp. 52-53). In the next section, I suggest that, intuitively speaking, Van Parijs's argument is problematic and I outline the remaining sections of the paper in which I offer a more systematic analysis of the problem.

\section{III}

Van Parijs's case for the unfairness of free-riding on the GLF is uncompelling. It rests on the analogy with Dust. And the conclusion about Dust rests on the assumption that it is unfair to free-ride on the father-in-law's cleaning efforts. Van Parijs seems to think that the unfairness in Dust is highly intuitive. It is not. I, for one, am more inclined to think it was objectionable for the father-in-law to impose his high standards of cleanliness on others, shaming them into participation. It does not seem right for the father-in-law to require contribution from others towards maintaining his personal standard-one he would have worked to meet in the absence of others, even though those others benefit from it.

Matters would differ, if the case were about the father-in-law taking up the dusting to maintain a non-met collectively agreed to standard of cleanliness (Dust*) or a non-met standard that, while not agreed to, can reasonably be considered as necessary for co-habiting a shared space (Dust **). In such scenarios, the unfairness in free-riding on the father-in-law's efforts would seem clear. I suspect that the intuitive appeal of Van Parijs's conclusion about Dust comes from the fact that the good in Dust subsumes that in Dust* and Dust**. That is to say, in meeting his higher personal standard of cleanliness, the father-in-law meets the standards in Dust* and Dust**. One might be tempted to think that the household members are unfairly free-riding because they are failing to do their fair share towards those standards in Dust* or Dust**. That might be right if we had reason to believe that the other family members were in any case not going to contribute to producing the goods (the cleanliness standards) in Dust* or Dust**. But the case, as Van Parijs sets it up, does not suggest they were idlers; rather, they were prevented from doing their fair share by the father-in-law's actions-actions meant to produce a good he deems in his interest (a permanently dust-free home). Intuitively, it seems mistaken to complain about their lack of contribution (let alone demand a contribution from them) on the grounds that they are unfairly free-riding. If anything ought to happen, it is for the household members to insist on setting an agreed-to standard (that of Dust** in the absence of agreement) that they then contribute to maintain fairly.

A first intuitive assessment suggests that free-riding on the father-in-law's selfimposed standard is not unfair. Furthermore, the case's complexity (because of the subsumed goods) makes it unhelpful as the base case for a compelling argument by analogy. For, it is not immediately clear whether the good of a GLF is analogous to 
the good in Dust in that way. ${ }^{7}$ As it stands, Van Parijs's defense of the unfairness of free-riding on the GLF seems unsuccessful.

I now move to provide a defense of the opposite conclusion: that free-riding on the GLF is not unfair because (1a) the production of the GLF is a case of self-serving production and (1b) free-riding on self-serving production efforts is not unfair. Next, I will suggest that an alternative claim is available for Van Parijs to make: that while free-riding on the GLF is not an instance of unfair free-riding, it is objectionable nonetheless. For (2a) if the co-operative production of a good is mandatory per standards of justice, then free-riders have a duty of justice to do their part in setting a co-operative scheme for its production, and free-riding is objectionable to the extent that it undermines that goal. And, Van Parijs believes that (2b) the GLF is required by demands of global justice.

Despite its complexity, Dust is helpful for my purposes because it foreshadows the distinction the paper relies on between three different types of production of public goods. Firstly, are cases where a public good is produced as a result of collective co-operative efforts (co-operative production). The good in Dust* would be such a good: the household collectively agrees to maintaining a particular standard of cleanliness. (1) Arguments for the impermissibility of free-riding appropriately apply to such cases, so I will argue. Secondly, are cases where a public good is produced by some agents for self-serving reasons (self-serving production). The good in Dust seems to be such a good: the father-in-law dusts to upkeep a standard of cleanliness of his preference. For a purer instance of self-serving production (one where the good does not subsume other goods) consider the case Netflix. An avid television series follower, the father-in-law subscribes to Netflix. Some error of setup makes the service available to all other family members on their personal devices at no further cost to the father-in-law. Other house members eagerly make use of the service. The family had not decided to subscribe to a media streaming service, and we can safely (?) assume having such a service is not mandatory for a functioning household. ${ }^{8}$ (2) Free-riding on self-serving production is not unfair free-riding, so I will argue. Thirdly, are cases where a public good should be co-operatively produced because its production is required by the just standards of a particular practice

\footnotetext{
7 Additionally, it is not clear that the Dust and the GLF cases are analogous. For we have reasons to be careful about drawing general conclusions from family examples and extending them to relations among strangers, especially when in the case of the latter we are concerned with duties of justice that can be enforceable. But, I set this worry aside for the rest of this paper. We can, for instance, think of Dust as a case involving flat-mates who do not have ties of friendship.

8 As an anonymous reviewer pointed out, Netflix is disanalogous to Dust and the GLF in that the beneficiaries can exclude themselves from the benefit by abstaining from using the service (which seems a reasonable cost). I do not think that the possibility of self-exclusion in the case of Netflix makes the charge of unfair free-riding more intuitive (it would be very mean-spirited if the father-in-law called up Netflix to inform them of the mistake - of course, there is a further disanalogy here seeing that Netflix can permissibly exclude the non-contributing beneficiaries). That said, the argument of this paper does not rest on whether the beneficiaries can exclude themselves from the benefit at reasonable cost. So, to the extent that one finds this feature of Netflix distracting, imagine that the benefit constitutes a free upgrade to the beneficiaries' paid memberships such that they can stream in better quality, with more options, and advertisement free.
} 
but which is not currently being produced co-operatively (mandatory goods). The good in Dust** would be such a good: the household fails to agree on a standard but having one is necessary for a functional household. (3) When mandatory goods are produced via self-serving production, producers and beneficiaries have the duty to transform its production into co-operative production. Free-riding is objectionable to the extent that it undermines that duty. Or so I will argue.

I develop arguments (1) and (2) in section "IV"; they support the conclusion that free-riding on the GLF is not unfair free-riding. I develop argument (3) in section "V"; it supports the alternative conclusion that if the GLF is a requirement of global justice, then free-riding, while not unfair to the non-Anglophones, may, nonetheless, be objectionable. In section 'VI', I consider and respond to a final potential objection to my argument.

\section{IV}

The intuition that one ought not to freely benefit from the public goods produced by others may seem to find support in what is referred to in the literature as the principle of fairness (or fair-play). The principle, first suggested by H.L.A. Hart (1955, p. 185) and later defended by Rawls (1999, p. 96), proscribes some forms of freeriding on public goods made available to us through the efforts of others.

A principle of fair play that requires contribution whenever one is a beneficiary of a public good is vulnerable to easy counterexamples. ${ }^{9}$ Restrictions on the scale and frequency of the interaction; size of the costs and benefits; and openness and avoidability of the benefit go a long way towards rendering the principle more plausible. But of high relevance to the question of this paper is a less often discussed restriction on the application of the principle. This is a restriction applied at the producer rather than the beneficiary end of the principle. ${ }^{10}$ It suggests that disallowing freeriding is most plausible for public goods that are produced by mutually advantageous co-operative schemes (henceforth co-operative schemes). I will refer to this restriction as the co-operative restriction.

Co-operative production schemes are schemes under which more than one individual co-operate to produce a mutually advantageous good according to a public system of rules that regulates the distribution of costs and benefits (Rawls 2001, p. 6). According to the co-operative restriction not every act of free-riding on public goods is unfair, even when the benefits received are important, continuous, and voluntarily enjoyed; free-riding is unfair when it involves benefitting from a co-operatively produced good. In other words, co-operative schemes are the appropriate site of the principle of fair play. ${ }^{11}$

\footnotetext{
${ }^{9}$ See Nozick (1974, pp. 93-94) for an example about benefitting from public-address entertainment system, and (more aptly for us) an example about a neighborhood dusting scheme.

${ }^{10}$ For accounts of beneficiary-side constraints see Arneson 1982, Klosko 1987, Simmons 1979, and Renzo 2014.

${ }^{11}$ Following Abizadeh (2007, p. 323), I use the site of a principle to refer to the 'kinds of objects (individuals' actions, individuals' character, rules, or institutions, and so on)' to which the principle in question rightly applies.
} 
The co-operative restriction can be defended by considering reasons for why free-riding on co-operative schemes is impermissible. To be sure, showing that freeriding on co-operative schemes is impermissible is not showing that co-operative schemes are the only type of production on which free-riding is impermissible. That said, I start from the supposition (backed by intuitions as in the section above) that free-riding on goods produced by others is not always impermissible. And seeing that a principle of fair play, that forbids free-riding, would generate potentially enforceable duties on free-riders, it would make sense to place the burden of proof on accounts that aim to expand the scope of its application (beyond appealing to intuitions). I discuss below two reasons that go to explain why it is reasonable to disallow free-riding on co-operative schemes; the reasons do not apply to other forms of free-riding.

\section{The instrumental argument}

Due to their non-excludable nature, the production of public goods is particularly vulnerable to collective action problems. Absent a scheme, it is in the interest of a potential beneficiary to not contribute to the production of a public good. For if enough people contribute to producing the good, that particular beneficiary will get to enjoy the good at no cost to herself. If, on the other hand, others do not contribute, then her contribution would have been a waste because the good will not come about through her single-handed effort. This is a problem: if potential beneficiaries reason in this way (and therefore end up not contributing), the good will not come about. Collective action problems that result in an undersupply of a good can be solved if potential beneficiaries can be provided the assurance that other beneficiaries will contribute to the production effort making everyone better off. Co-operative schemes provide the needed assurance: they regulate the production and maintenance of public goods according to a system of public and fair rules under which participants contribute while being secure in the knowledge that others have bound themselves to contribute to the scheme.

The principle of fair play has a role to play in addressing the problem of undersupply. Consider the production of a pollution-free environment. The production and maintenance of a low-pollution environment (at least in standard cases) is highly vulnerable to the problem of undersupply. For example, we know that urban vegetation such as green roofs or climbing ivy, if sufficiently widespread, improves local air quality (Susorova et al. 2014; Oberndorfer et al. 2007). But there is an associated cost for planting and efficiently maintaining such vegetation, and it makes sense for an individual to reason as follows: if enough others plant I will benefit from cleaner air, and if not enough others plant then I would be wasting my money because my plants will not make a difference. So, it is better for me not to plant. ${ }^{12}$ While leaving the planting of vegetation up to individuals is therefore very likely to lead to undersupply, setting up a fair scheme of co-operation under which everyone commits to

\footnotetext{
12 I assume here that individuals do not have independent, say aesthetic reasons, to plant the requisite vegetation. I also assume that individual planting initiatives make no local difference to the quality of air.
} 
planting or contributing to the associated cost can provide the needed assurance to produce and maintain cleaner air. And the principle of fair play can, here, be instrumental to dissuading individuals from withholding their participation in the scheme in the hope that others would be moved to set it up. By disallowing free-riding and generating an enforceable claim by producers against free-riders, the principle eliminates any incentive those tempted to wait it out may have ${ }^{13}$ it would thus facilitate, accelerate, and sustain the formation of co-operative schemes. ${ }^{14}$

But the problem of undersupply does not capture all that there is to co-operative schemes that makes them appropriate sites of the principle of fair play. While the problem of undersupply gives us a reason to set up fair schemes of co-operation that are subject to the principle of fair play, it is ineffective with regard to newcomers to an already established scheme. It is ineffective because participants in an established co-operative scheme cannot appeal to the problem of undersupply and the instrumental argument for the principle of fairness to dissuade newcomers from free-riding on the scheme; the scheme is already running, the members of the scheme are bound to it, the good is in supply, and is non-excludable and non-rival. Yet it does not seem right for newcomers to a green town, for instance, to benefit from a pollution reduction scheme without contributing to it. The argument I consider next morally blocks those tempted to free-ride on established schemes from doing so by providing us with a reason to apply the principle of fair play to co-operative schemes even when there is no problem of undersupply.

\section{The non-instrumental argument}

In a series of articles Paula Casal and Andrew Williams (Casal and Williams 2007; Casal 1999) defend a non-instrumental argument for the co-operative restriction. According to Casal and Williams (2007, p. 106), the principle of fair play is most plausible when applied to co-operative schemes because it protects the co-operative producers' sense of duty. For as they point out, co-operative producers submit themselves to the constraints of co-operative schemes because their submission is necessary for producing the good. Casal and Williams's argument for the co-operative restriction is highly perceptive. And in what follows I will offer a reconstruction and interpretation of their argument.

Casal and Williams appeal to Rawls's stated rationale for the principle of fair play in defending the restriction. Rawls's (1999, p. 96) rationale for the requirement that one does her part under a just institutional scheme, worth quoting in full, is as follows:

\footnotetext{
13 The question of whether and how we can effectively disallow free-riding is a difficult question. We are interested here in the question of moral disallowance.

14 That the scheme be internally fair is another condition for facilitating the set-up and for maintaining a sustainable co-operative scheme. In taking up the question of what constitutes a fair distribution of cost and benefit in the production of the GLF, Van Parijs mainly concerns himself with discussing the internal fairness of a co-operative scheme. The question of the internal fairness of a scheme is only relevant, however, once we have established that there is (or must be) a scheme in the first place.
} 
The main idea is that when a number of persons engage in a mutually advantageous co-operative venture according to rules, and thus restrict their liberty in ways necessary to yield advantages to all, those who have submitted to these restrictions have a right to similar acquiescence on the part of those who have benefited from their submission. We are not to gain from the co-operative labors of others without doing our fair share.

Rawls, as the quote makes clear, sees the principle of fair play as a guarantor for those engaging in mutually advantageous co-operative labor that their compliance with the scheme will not be taken advantage of. But what is it about co-operative labor that makes it singularly deserving of protection against free-riding? What makes compliance with the demands of a co-operative scheme worthier of protection than commitment to one's self-serving goals? Casal and Williams suggest Rawls's answer: that we ought not to take advantage of those who 'restrict their liberty in ways necessary to yield advantages to all'. We can appreciate Casal and Williams's point (and Rawls's) by unpacking this statement.

From the discussion of the undersupply problem above, we know that co-operative schemes regulated by rules are necessary for a mutually advantageous good to come about. This suggests that the restriction of liberty that Rawls refers to is the one that results when one submits herself to the system of rules and to the constraints of co-operation. Casal and Williams take the cost associated with this restriction of liberty (submission to authority) to be morally significant; they suggest that it generates a claim by co-operators against potential free-riders that they not benefit without bearing a share of the cost. The cost associated with submitting to a co-operative scheme is morally significant because it is borne out of commitment and submission to the co-operative scheme, or, put differently, out of a 'sense of duty' towards the co-operative community. ${ }^{15}$ The particular wrongness of freeriding on goods produced through co-operative schemes lies in the fact that by freeriding one would be taking advantage of the producers' commitments to the scheme, their sense of duty.

The concern with protecting producers from having their sense of duty exploited explains why we think free-riding on co-operative environmental efforts is unfair even in the absence of a problem of undersupply. To a free-rider, a compliant contributor to the scheme can say, 'I could also free-ride and get the benefits at zero cost, but I do not because I have submitted out of duty to the demands of co-operation in this scheme, a scheme which needs to exist if we are all to benefit'. Compare with Netflix which does not involve co-operative production. The benefit of enjoying access to television comes about because the father-in-law loves television. His reasons for taking up the subscription are self-serving. It makes no sense to think that he subscribed to the service out of a sense of a moral duty. The father-in-law seems

\footnotetext{
15 Williams (2014, p. 5) puts the wrongness of free-riding in terms of 'exploitation' of the co-operative producers' 'sense of duty'.
} 
to have no complaint against free-riders that is equivalent to that submitted by the contributor to the co-operative environmental scheme. ${ }^{16}$

The implications of the co-operative restriction for our assessment of the permissibility of free-riding on the GLF seem clear: the production of the GLF cannot be seen to be the result of a co-operative scheme in the relevant sense; Anglophones cannot be said to be unfairly free-riding, and non-Anglophones have no claim of compensation against Anglophones. To be sure, learning and using a language involves co-operative interaction in some sense; it is not, however, the relevant sense for triggering the application of the principle of fair play. Whatever co-operation is involved in producing the GLF it is neither meant to solve the problem of undersupply nor carried out from a sense of duty towards others in a co-operative scheme. Rather, much like the father-in-law in Netflix, non-Anglophones who produce the GLF are acting to produce outcomes for self-serving reasons. Indeed, Van Parijs (2011, pp. 9-19) points out that the spread of English as a GLF was put on track by historical contingencies against which micro-mechanisms regulating the learning and the speaking of a language worked to establish English as the prime contender for a GLF. He is careful to point this out so as to avoid objections to accepting English as a GLF on the grounds that its spread is a result of injustice (for instance, the imposition of English through unjust wars). If Van Parijs is right about the way English came to be the global lingua franca, then the spread of English was not imposed, but nor was it the result of co-operation. And if this is correct, we can safely affirm that non-Anglophones have not been bearing the cost of producing the GLF as part of a co-operative scheme out of a sense of commitment for producing a public good. While non-Anglophones certainly contribute to the production of a public good when they learn English, they learn it for self-serving reasons. Such reasons are likely to range from the wish to seek better job opportunities, to the wish to study abroad, facilitate one's travels, or read untranslated English literature. In this, non-Anglophones are very much producing self-serving goods; the principle of fair play does not disallow free-riding on the benefits their activities generate.

\footnotetext{
${ }^{16}$ Here, one might point out that many public goods are produced through a combination of self-serving and duty-oriented reasons, shedding doubt on the distinction between co-operative and self-serving production. There are two things to note in response. Firstly, to the extent that this is a complication it has no bearing on the case of the GLF at hand; it seems safe to assume that the vast majority of non-Anglophones do not have mixed reasons for learning English. Secondly, and more importantly, when one submits to the demands of a co-operative scheme, their reasons to act in accordance with the demands of it pre-empt other reasons they may have to see $\operatorname{Raz}(1988,38-44$; 1999, 37-45), for discussion of pre-emptive reasons and for how obligations can be protected by exclusionary reasons to disregard other reasons for action). This also helps explain the significance of the existence of a co-operative scheme with public rules versus informal collaboration: the authority of the scheme and the publicity of the rules allow us to say that producers comply out of duty. I thank an anonymous reviewer for pressing me to address this, helping make this point clearer.
} 
We would be too quick, however, if following the co-operative restriction we were to conclude that Anglophones are off the hook when it comes to the costs of producing the GLF. For while the GLF may not be a result of co-operative production, it is a separate question whether it should be co-operatively produced. In this section, I argue that goods that are required by justice, what I call mandatory public goods, ought to be produced through a co-operative scheme. This requires that both beneficiaries and contributors have a duty to set up the co-operative scheme. Moreover, I suggest that actions which undermine the co-operative production of mandatory goods are unjust. To the extent that free-riding undermines the possibility of cooperative production, it is unjust.

We can distinguish between two types of goods: mandatory and non-mandatory goods. Mandatory goods are goods whose provision is required in a just society. They are goods that justice requires that individuals have to some relative or absolute degree. Rawls's primary goods (Rawls 1999, pp. 78-81) are, for instance, mandatory goods. But so are goods that are needed for producing and distributing those primary goods, and so are goods that are required for getting people to comply with demands of justice. ${ }^{17}$

Mandatory public goods are mandatory goods that are non-rival and non-excludable. We could think of a public education system, for instance, as a mandatory public good; it is required if a society is to equalize opportunities among its members; it is also required for developing members' sense of justice. Peace, too, is a mandatory public good; it is required for developing stable global institutions needed for global justice. Non-mandatory goods, on the other hand, are not required as a matter of justice; these are goods that may be desirable and could be highly valuable to individuals but that society has no obligation to provide as a matter of justice. Public radio may be one such example.

With this definition of mandatory goods in mind, consider the following case (call it Toxic Air): earth is hit by a meteorite and as a result becomes dangerously polluted with toxic gas. A number of scientists driven by the love of science and the thrill of the challenge invent a machine that purifies the planet's air, and driven by the same motivations, they maintain it and improve it for years. It should be clear by now that on the co-operative restriction view the inhabitants of earth would not be unfairly free-riding on the scientists' efforts if they refuse to subsidize the cost of inventing and sustaining the machine. For although the public good of a purified air is the outcome of the scientists' actions, the scientists do not take up the cost of producing the outcome for the sake of the common benefit; they take it up for the thrill of discovery. ${ }^{18}$

\footnotetext{
17 Klosko $(1987,1990)$ makes a similar distinction between presumptive and discretionary goods. Also see the distinction between essential and discretionary goods in Miller and Taylor (2018) and Taylor (2014). Casal (1999) uses the term unconditional goods for what I call mandatory goods.

18 There may of course be many non-fairness related and incentive-related reasons to subsidize scientific discovery, but what concerns us here are reasons grounded in the principle of fair play.
} 
While the purification in Toxic Air is not co-operatively produced, it is a separate question, however, whether it ought to be. It is safe to assume that non-toxic air is a mandatory public good, a good that everyone should have access to as a matter of justice. Being a mandatory good is a reason, or so I will argue, for ensuring that the good is produced via a co-operative scheme, one to which all the beneficiaries contribute. Before elaborating on why I think the production of mandatory goods requires the setting up of co-operative schemes, I want to briefly consider a possible line of argument for that conclusion that may at first seem appealing but that, I suggest, ultimately fails.

One might argue that if mandatory goods are goods that everyone should have access to as a matter of justice, then a corollary is that everyone has a duty to contribute (their share) to making that good available to others. ${ }^{19}$ The fact that non-toxic air is a mandatory good means not only that everyone ought to have access to clean air but also that everyone has a duty to contribute to its production. Indeed, absent the contribution of the invention-loving scientists we would think that the cost of producing and maintaining the machine ought to be borne by every inhabitant, and, adjusting for just background conditions, borne equally. We can therefore conclude that all inhabitants have a duty to contribute to the production of cleaner air. And, it may seem plausible to think that the devoted scientists would have a valid complaint against non-contributing inhabitants; by refusing to contribute, the inhabitants would be failing their duty to produce a mandatory good.

Granted, the inhabitants have a duty to purify the air, but the duty is meant to ensure that a particular outcome comes about, not that the duty bearers take up the cost. We would think that the duty becomes redundant if the air gets purified without their contribution, say due to some natural climatic change. Why would we not think the same when the air gets purified because some thrive on scientific challenges? It would be morally dishonest for the scientists to say to the inhabitants "we did more of our share of duty; it is only fair for you to do yours', since, as per the assumptions of the case, they did not produce the machine out of a sense of duty, but would have produced it in any case.

The reason I think the inhabitants should contribute to the cost of the purification is different. I submit that the provision of a mandatory good should be secured and not left to the whims of some. If inhabitants were to have no obligation to contribute to the cost of purifying the air, it leaves it open to the scientists to, at any point, threaten the inhabitants with, 'if you do not pay, we can simply abandon this project and move on to others'. And it seems that it would be morally permissible for the scientists to abandon the project. ${ }^{20}$ But this puts the scientists in a position to, in some sense, blackmail the inhabitants and leaves the inhabitants unsecure in the knowledge that they will have access to the mandatory good in question. This

\footnotetext{
19 This seems to be the suggestion in Casal (1999, pp. 369-370).

${ }^{20}$ One might think that the scientists have some duty of assistance to not abandon the project, if not towards the inhabitants refusing to contribute then to those who are incapable of contributing (children for instance). But I want to set this aside; suppose, for instance, that the scientists have already fulfilled their 'quota' of assistance by dedicating large portions of their income and time to fighting malaria.
} 
seems to me to be a case of objectionable domination, a state that I believe would be deeply problematic. It gives us, I suggest, strong reasons to ensure that the production of mandatory goods is the outcome of a co-operative scheme where the pool of beneficiaries and producers coincides, where the production of the good is regulated by a public and fair system of rules, and where the participants are bound to the scheme out of a sense of duty-in this case, the duty towards others to ensure that the production of the mandatory good is not vulnerable to objectionable domination.

If I am right that mandatory goods ought to be co-operatively produced as a matter of justice, then it would seem that actions that undermine their co-operative production are objectionable. Beneficiaries and contributors have a duty to set up a co-operative scheme. And to the extent that free-riding undermines the set-up of such a scheme (for the reasons discussed in the undersupply problem), free-riding is impermissible. ${ }^{21}$ The impermissibility, however, is not grounded in an unfairness of free-riding on productive efforts of others but in the unjust undermining of the establishment of a co-operative scheme necessary for domination-free production.

Put differently, when it comes to mandatory goods that are spontaneously produced, free-riding is impermissible not because producers have a claim that others not free-ride on their efforts without contributing their fair share, but because each member of the community (but especially beneficiaries) has a claim that mandatory goods be produced via schemes that are governed by a public system of rules. One important upshot of this, is that producers have no claim of compensation against beneficiaries. To be clear, the claim here is not (merely) that once a co-operative scheme is set up then free-riding is impermissible (for this is true for both mandatory and non-mandatory goods); rather it is that free-riding would be impermissible to the extent that it undermines the creation of the scheme (as per the reasons discussed in the undersupply argument). ${ }^{22}$

This conclusion, if correct, may allow Van Parijs to condemn the free-riding Anglophones, but for different reasons than that of unfair free-riding. Van Parijs believes that a GLF is required by global justice. If he is right then a GLF is a mandatory good. To be sure, a GLF does not seem mandatory in the sense that we think persons must have access to it as a requirement of distributive justice. There is,

\footnotetext{
21 It is unclear to me whether Casal or Williams endorses this argument from mandatory goods. Casal (1999, pp. 369-370) suggests that free-riding on clean air produced by a group which has a retrofitting converter fetish is not unfair. And while she points out that there are justice-based reasons for producing clean air, she does not present these reasons as reasons for setting up co-operative schemes or for prohibiting free-riding.

22 This suggests that producers who continue to unilaterally supply mandatory goods would also be acting unjustly, to the extent that such unilateral supply undermines the set-up of a co-operative scheme. If correct, then we might ask whether the scientists in Toxic Air should be stopped from purifying the air until a scheme is set up, or if the government may forcibly nationalize their purifying technology. The former seems hard to justify, for it is a clear case of leveling down. Nationalizing the technology might raise concerns of property rights violation or inefficiency (in view of the adverse incentives it might have). While I see that there can still be good reasons to nationalize, we might want to consider alternatives which allow the scientists to continue the production while protecting the beneficiaries from domination. For instance, we could ask the scientists to either relinquish the technology or incur a duty to continue producing. I thank an anonymous reviewer for raising the objection and suggesting the alternative.
} 
however, another sense in which a GLF may be thought to be a mandatory good. According to Van Parijs (2011, pp. 24-31), a GLF is necessary for both grounding and achieving global egalitarian justice. If he is right, then a GLF would seem necessary for the provision of other mandatory goods. Van Parijs argues that a GLF is necessary for grounding and achieving global egalitarian justice for two reasons. Firstly, having a GLF allows people from different circles of solidarity to communicate as equals and arrive at the conclusion that a global egalitarian conception of justice is the only conception that takes seriously their status as equals. Secondly, having a transnational demos is necessary for applying principles of global justice; absent a transnational forum for deliberation and activism accessible to all the principles of global justice would never become feasible. And a GLF is necessary for a transnational demos.

I do not wish here to evaluate the plausibility of Van Parijs's claim that the GLF is a requirement of global justice. But I want to note two ways in which pushing this line of argument comes at a cost. Firstly, it comes at the expense of the ecumenical appeal that Van Parijs intended for his claim that there is injustice in free-riding on the GLF. For one, it is very controversial that having a GLF is necessary for either grounding or achieving global justice (for critiques see Taylor 2014; Lacey 2015). Moreover, this argument appeals only to those who believe egalitarian global justice is the right ideal, but global egalitarianism does not have a shortage of critics (for an overview of the debate around global justice see Blake and Smith 2020; Brock 2017). Secondly, it no longer allows Van Parijs to claim that Anglophones owe nonAnglophones compensation, for the wrongness of free-riding does not lie in having benefitted from their effort but in the (forward-looking) duty to set up a co-operative scheme.

\section{VI}

In this final section I want to consider an external objection to the conclusion that the principle of fair play does not apply to free-riding on the GLF. ${ }^{23}$

The objection goes as follows: in today's world, non-native English speakers who learn English are not like the father-in-law and Netflix, nor like the discoveryseeking scientists. For while the latter two produce the good out of self-serving reasons, non-Anglophones have little choice but to learn English. A non-Anglophone learning English may be similar to the television binge-watcher and the scientist if he were learning English in order to read Jane Austen untranslated. But most nonAnglophones do not learn English for such purposes. For many, learning English is necessary if they are to successfully pursue their chosen career options. This is because English has become a prerequisite for many jobs. This is clearest in the case of jobs that involve international co-operation and in jobs where knowledge and advances in the relevant field are produced in English. Hence being an aid worker, a telecom regulator, a surgeon, or a philosopher all require that one knows English

${ }^{23}$ I am grateful to Helder de Schutter for raising this objection. 
if one is to be successful at her job. This makes Anglophones free-riders on nonAnglophones' misfortune, the misfortune of having to learn English if they are to pursue the jobs they want for themselves. And this makes the free-riding problematic on non-Anglophones unfair in a way that justifies compensation.

The objection seems compelling. To see its force, suppose that in Dust the fatherin-law's reason for excessive cleaning is that he suffers from a serious dust allergy. It might seem right, in this case, to think it problematic for one to free-ride on his misfortune. One could argue that the situation of non-Anglophones is analogous to the sickly father-in-law's.

Let us accept as true the empirical premises of the objection, that non-Anglophones learn English out of necessity. The intuition that it would be unfair to freeride on the non-excludable goods produced by the sickly father-in-law and by nonAnglophones seems to be driven by the thought that their misfortune is unchosen. But there seems to be an important difference between the sickly father-in-law's misfortune (having to continuously dust his home to avoid allergies) and that of nonAnglophones (having to learn the global lingua franca because it is not their native language): only the father-in-law's misfortune strikes me as a burden itself.

Compare the respective sources of misfortune: having allergies and having a native language that is not English. I take it that we would quite readily say that being allergic is a burden; we would, however, be much more reluctant to conclude the same about having a native language that is not English. It seems to me that the difference in our judgment arises because we think that a person with dust allergies would readily do without the allergies altogether, indeed seek treatment. We would, however, think that most non-Anglophones do not see their native language as a burden to do away with (I take as evidence for this the efforts linguistic communities undertake to protect their language). ${ }^{24}$ To the extent that non-Anglophones are attached to their native languages, they are like the fastidious father-in-law in the original Dust case, or the devoted scientists in Toxic Air: they endorse rather than reject their preferences. ${ }^{25}$ Free-riding on the goods they produce does not strike me as unfair. Their situations are importantly different from someone who has to bear the cost of producing the good out of a predicament they do not endorse.

\section{VII}

I have argued that not all free-riding on public goods is unfair. And I suggested that concern with the fairness of free-riding on public goods does not arise when the goods are the outcome of self-serving production efforts and when there are no

\footnotetext{
${ }^{24}$ I realize this is a generalization. There may be communities which would take switching altogether to English any day, but then perhaps the problem of learning English for them is a one-off thing compared with others for whom it will be a requirement generation after generation.

25 Another way of putting the argument is in terms of the expensive tastes debate. We can distinguish between goods whose production is made necessary by bad brute luck and goods (akin to expensive tastes) whose production cannot be seen as bad brute luck because the good is endorsed. For the expensive taste argument See, Dworkin (2000, pp. 11-64).
} 
justice-based reasons for setting up co-operation. Our concern with fairness of freeriding arises when producers bind themselves to the production of a good out of a sense of commitment to others. But goods required by justice ought to be produced co-operatively to protect beneficiaries from objectionable domination by producers. If GLF is a good required by global justice then both Anglophones and non-Anglophones have a duty to set up a co-operative scheme to produce it, and free-riding would be impressible to the extent that it undermines acting on such a duty. Either way, non-Anglophones are not owed compensation for the costs they have incurred.

Acknowledgements Earlier versions of this paper were presented at workshops in Aarhus University and KU Leuven and at the Globalizing Minority Rights conference in Copenhagen. I would like to thank workshop participants as well as Andreas Albersten, Sara Amighetti, Niels Holtug, Kasper Lippert-Rasmussen, and Tim Meijers for helpful comments and probing questions. I am especially grateful to Helder De Schutter and to Andrew Williams for conversations and excellent written comments.

Funding Part of this article was written during my doctoral fellowship, funded by FWO-Research Foundation Flanders.

\section{Compliance with Ethical Standards}

\section{Conflict of interest None identified.}

Open Access This article is licensed under a Creative Commons Attribution 4.0 International License, which permits use, sharing, adaptation, distribution and reproduction in any medium or format, as long as you give appropriate credit to the original author(s) and the source, provide a link to the Creative Commons licence, and indicate if changes were made. The images or other third party material in this article are included in the article's Creative Commons licence, unless indicated otherwise in a credit line to the material. If material is not included in the article's Creative Commons licence and your intended use is not permitted by statutory regulation or exceeds the permitted use, you will need to obtain permission directly from the copyright holder. To view a copy of this licence, visit http://creativecommons.org/licen ses/by/4.0/.

\section{References}

Abizadeh, Arash. 2007. Co-operation, Pervasive Impact, and Coercion: On the Scope (Not Site) of Distributive Justice. Philosophy \& Public Affairs 35(4): 318-358.

Arneson, Richard J. 1982. The Principle of Fairness and Free-Rider Problems. Ethics 92(4): 616-633.

Blake, Michael, and Patrick Taylor. Smith. 2020. International Distributive Justice. In The Stanford Encyclopedia of Philosophy (Summer 2020 Edition), ed. Edward N. Zalta.

Brock, Gillian. 2017. Global Justice. In The Stanford Encyclopedia of Philosophy (Spring 2017 Edition), ed. Edward N. Zalta.

Casal, Paula. 1999. Environmentalism, Procreation, and the Principle of Fairness. Public Affairs Quarterly 13(4): 363-376.

Casal, Paula, and Andrew Williams. 2007. Equality of Resources and Procreative Justice. In Dworkin and His Critics, ed. J. Burley, 150-169. Hoboken, NJ: Blackwell Publishing Ltd.

De Schutter, Helder and Robichaud, David (Eds). 2016. Linguistic Justice, Van Parijs and his Critics. New York: Routledge

Dworkin, Ronald. 2000. Sovereign Virtue: The Theory and Practice of Equality. Cambridge, MA: Harvard University Press.

Hart, H. L. A. 1955. Are There Any Natural Rights? The Philosophical Review 64(2): 175-191.

Ives, Peter. 2009. Cosmopolitanism and Global English: Language Politics in Globalisation Debates. Political Studies 58(3): 516-535. 
Klosko, George. 1987. The Principle of Fairness and Political Obligation. Ethics 97(2): 353-362.

Klosko, George. 1990. The Obligation to Contribute to Discretionary Public Goods. Political Studies 38(2): 196-214.

Lacey, Joseph. 2015. Considerations on English as a GLF. Political Studies Review 13(3): 363-372.

Miller, David, and Taylor, Isaac. 2018. Distributive Justice and Public Goods. In The Oxford Handbook of Distributive Justice, ed. Serena Olsaretti. Oxford: Oxford University Press.

Nozick, Robert. 1974. Anarchy, State, and Utopia. New York: Basic Books.

Oberndorfer, Erica, Lundholm, Jeremy, Bass, Brad, Coffman, Reid, Doshi, Hitesh, Dunnett, Nigel, et al. 2007. Green roofs as urban ecosystems: Ecological structures, functions, and services. Bioscience 57: 823-833. https://doi.org/10.1641/B571005.

Ostrom, Vincent, and Elinor Ostrom. 2015. Public Goods and Public Choices. In Elinor Ostrom and the Bloomington School of Political Economy, vol. 2 Resource Governance, ed. Daniel H. Cole and Michael D. McGinnis, 3-36. Lanham, MD: Lexington Books.

Rawls, John. 1999. A Theory of Justice. Cambridge, MA: Harvard University Press.

Rawls, John. 2001. Justice As Fairness: A Restatement, ed. Erin Kelly. Cambridge, MA: Harvard University Press.

Raz, Joseph. 1988. The Morality of Freedom. Oxford: Oxford University Press.

Raz, Joseph. 1999. Practical Reason and Norms. Oxford: Oxford University Press.

Réaume, Denise. 2015. Lingua Franca Fever: Sceptical Remarks. Critical Review of International Social and Political Philosophy 18(2): 149-163.

Renzo, Massimo. 2014. Fairness, Self-Deception and Political Obligation. Philosophical Studies 169(3): 467-488.

Robichaud, David. 2015. Co-operative Justice and English as a Lingua Franca: The Tension between Optimism and Anglophones Free Riding. Critical Review of International Social and Political Philosophy 18(2): 164-177.

Romaine, Suzanne. 2015. Linguistic Diversity and Global English. In Language Policy and Political Economy English in a Global Context, ed. T. Ricento. Oxford: Oxford University Press.

Simmons, A. John. 1979. The Principle of Fair Play. Philosophy \& Public Affairs 8(4): 307-337.

Susorova, I., P. Azimi, and B. Stephens. 2014. The Effects of Climbing Vegetation on the Local Microclimate, Thermal Performance, and Air Infiltration of Four Building Facade Orientations. Building and Environment 76: 113-124.

Swain, Harriet. 2014. Lack of Languages Stifles British and American|Education/The Guardian. https:// www.theguardian.com/education/2014/jul/08/lack-of-languages-stifles-brits-americans.

Taylor, Isaac. 2014. Language as a Global Public Good. Res Publica 20(4): 377-394.

Van Parijs, Philippe. 2002. Linguistic Justice. Politics, Philosophy \& Economics 1(1): 59-74.

Van Parijs, Philippe. 2011. Linguistic Justice for Europe and for the World. Oxford: Oxford University Press.

Williams, Andrew. 2014. Demography and Distribution. Unpublished Article.

Publisher's Note Springer Nature remains neutral with regard to jurisdictional claims in published maps and institutional affiliations. 